\title{
Adsorpsi Unsur Pengotor Larutan Natrium Silikat Menggunakan Zeolit Alam Karangnunggal
}

\author{
${ }^{1}$ Thamzil Las, ${ }^{2}$ Florentinus Firdiyono, ${ }^{1}$ Afit Hendrawan \\ ${ }^{1)}$ Program Studi Kimia FST UIN Syarif Hidayatullah Jakarta \\ ${ }^{2)}$ Pusat Penelitian Metalurgi LIPI Gedung 470 Kawasan PUSPIPTEK Serpong, \\ Tangerang 15314
}

\begin{abstract}
Abstrak
Penelitian tentang kemampuan penyerapan zeolit alam Karangnunggal sebagai sorben dalam larutan natrium silikat telah dilakukan. Penelitian ini bertujuan untuk mengetahui efisiensi penyerapan zeolit terhadap unsur pengotor larutan natrium silikat serta mengetahui hubungan penyerapan zeolit dengan beberapa parameter adsorpsi. Untuk itu proses adsorpsi dilakukan dengan beberapa parameter, diantaranya waktu kontak, massa sorben, $\mathrm{pH}$, temperatur. Hasil analisa menggunakan Spektroskopi Serapan Atom (SSA) menunjukkan bahwa zeolit alam Karangnunggal yang diaktivasi dengan $\mathrm{H}_{2} \mathrm{SO}_{4}$ dapat digunakan untuk menyerap $\mathrm{Fe}^{3+}$ dalam larutan natrium silikat. Kondisi optimum penyerapan $\mathrm{Fe}^{3+}$ dalam larutan natrium silikat dicapai dengan parameter waktu kontak selama 60 menit, massa zeolit yang digunakan sebanyak 3 gram, $\mathrm{pH} 3$, dan pada temperatur ruang. Tetapi zeolit tersebut tidak efektif untuk menyerap $\mathrm{Mg}^{2+}$ dan $\mathrm{Ca}^{2+}$ dalam larutan natrium silikat.
\end{abstract}

Kata Kunci : Natrium Silikat, Zeolit Alam Karangnunggal, Aktivasi Zeolit, Persen Penyerapan, Spektroskopi Serapan Atom.

\begin{abstract}
Research studies on the adsorption capacity of Karangnunggal natural zeolite as a sorbent in solution of sodium silicate has been done. This study aims to determine the efficiency of adsorption of the zeolite to a solution of sodium silicate impurity elements and know the relationship between the adsorption of the zeolite with the adsorption parameters. For the adsorption process carried out by several parameters, such as contact time, sorbent mass, $\mathrm{pH}$, temperature. Results of analysis using Atomic Absorption Spectroscopy (AAS) showed that Karangnunggal natural zeolite activated with $\mathrm{H}_{2} \mathrm{SO}_{4}$ can be used to adsorb $\mathrm{Fe}^{3+}$ in sodium silicate solution. The optimum condition of the adsorption of $\mathrm{Fe}^{3+}$ in sodium silicate solution is achieved with contact time parameters for 60 minutes, the mass of zeolite is used as much as 3 grams, $\mathrm{pH} 3$, and at room temperature. However, these zeolites is not effective to adsorb $\mathrm{Mg}^{2+}$ and $\mathrm{Ca}^{2+}$ in a solution of sodium silicate.
\end{abstract}

Keywords : Sodium Silicate, Karangnunggal Natural Zeolite, Zeolite Activation, Percen Adsorption, Atomic Absorption Spectroscopy.

\section{PENDAHULUAN}

Indonesia memiliki potensi sumber daya energi terbarukan yang melimpah antara lain energi surya, hal ini dikarenakan letak Indonesia yang berada di daerah tropis yang menerima sinar matahari sepanjang tahun. Energi ini dapat digunakan sebagai sumber energi alternatif. Akan tetapi pengembangan energi alternatif ini terbentur dengan mahalnya peralatan panel surya impor. Peralatan panel surya tidak dapat diproduksi di dalam negeri karena ketersediaan silikon murni untuk bahan pembuatan panel surya belum mampu dibuat di Indonesia.

Penggunaan pasir kuarsa di Indonesia masih terbatas pada industri gelas kaca, semen, tegel, mosaik keramik, dan ampelas. Pasir kuarsa yang terdapat di Indonesia meskipun memiliki kemurnian yang tinggi dengan penampakan kristal yang bagus, ternyata memiliki pengotor yang membentuk senyawa kompleks. Senyawa 
kompleks terbentuk antara kristal silika dengan pengotor yang mengandung oksida besi, aluminium, titanium, kalsium, magnesium dan lain-lain. Pasir kuarsa tersebut tidak dapat dijadikan sebagai bahan baku silikon murni untuk pembuatan panel surya dengan proses pencucian biasa. Untuk itu diperlukan terobosan proses pengolahan pasir kuarsa menjadi silika murni sebagai bahan baku pembuatan silikon dengan kemurnian tinggi. Diperlukan paling tidak silikon dengan kemurnian 99,999\% sebagai syarat bahan baku untuk panel surya (Stanitski, 2003).

Pemurnian silika biasanya dilakukan dengan penambahan asam klorida ( $\mathrm{HCl})$. Pemurnian ini hanya menghasilkan silika dengan kadar 99,99\% (Aulich, et al, 1984) dan (Sulistiyono, et al, 2000). Hal ini dikarenakan $\mathrm{HCl}$ hanya mengikat unsur pengotor yang ada di permukaan silika. Untuk mendapatkan silika dengan kadar 99,999\% maka dilakukan penyerapan unsur pengotor dengan zeolit. Zeolit adalah mineral dengan struktur kristal alumino silikat yang berbentuk framework (struktur tiga dimensi), dan mempunyai rongga serta saluran yang diisi oleh kation logam alkali dan atau alkali tanah serta molekul air. Ion logam dan molekul air dapat digantikan oleh ion atau molekul lain secara reversibel tanpa merusak struktur zeolit, sehingga zeolit dapat digunakan untuk menyerap ion logam. Sampai saat ini telah ditemukan lebih dari 50 jenis zeolit alam (Suhala, 1997). Namun yang mempunyai nilai komersil diantaranya adalah jenis klinoptilolit, mordenit, filipsit, kabazit, erionit, ferrierit dan faujasit (Dyer, A.1988).

Jenis mineral zeolit yang sering ditemukan di Indonesia adalah klinoptilolit dan mordenit (Las, T. 2006). Zeolit merupakan salah satu mineral yang banyak terdapat di Kabupaten Tasikmalaya dengan penyebaran deposit di daerah Karangnunggal, Cipatujah dan Cikalong dengan deposit kurang lebih 39.435.125 ton. Zeolit alam Karangnunggal sudah dikarakterisasi dan merupakan jenis mordenit (Sulistiyono, et al, 2009). Zeolit ini dapat digunakan untuk menyerap kromium (Cr) (Handayani, et al, 2009) dan nikel (Ni) (Yuhelda, 2004) dalam air limbah.
Untuk mendapatkan silikon dengan kemurnian sampai 99,999\% maka langkah pertama adalah melakukan upaya pengembangan proses pemurnian bahan baku pasir kuarsa alam. Diharapkan pasir kuarsa tersebut terbebas dari bahan pengotor dan dapat dijadikan bahan baku silikon murni untuk pembuatan panel surya. Untuk itu pada penelitian ini akan dilakukan proses peleburan pasir kuarsa dengan senyawa alkali natrium karbonat $\left(\mathrm{Na}_{2} \mathrm{CO}_{3}\right)$. Pada proses ini diasumsikan terjadinya pemecahan ikatan di dalam pasir kuarsa tersebut. Hasil dari proses peleburan ini adalah natrium silikat $\left(\mathrm{Na}_{2} \mathrm{SiO}_{3}\right)$ yang kemudian dilarutkan dan dilanjutkan dengan proses pemisahan unsur pengotor yang mungkin masih terkandung dalam larutan natrium silikat. Eliminasi unsur pengotor yang terdapat dalam larutan natrium silikat dalam penelitian ini dilakukan dengan menggunakan zeolit alam Karangnunggal. Eliminasi tersebut berlangsung melalui proses adsorpsi. Dengan proses ini diharapkan kadar unsur pengotor yang terdapat dalam larutan natrium silikat seperti besi (Fe), magnesium (Mg), dan kalsium (Ca) dapat dikurangi karena terserap oleh zeolit alam Karangnunggal.

Penelitian ini dilakukan untuk mengetahui kondisi optimum penyerapan zeolit dan hubungan kemampuan penyerapan unsur pengotor oleh zeolit alam Karangnunggal dengan variasi waktu kontak, massa, $\mathrm{pH}$ dan temperatur. Melalui penelitian ini diharapkan dapat memberikan informasi tentang pemanfaatan zeolit alam Karangnunggal sebagai penyerap unsur pengotor dalam larutan natrium silikat sehingga dapat meningkatkan nilai tambah mineral pasir kuarsa.

\section{METODE PENELITIAN}

\section{Waktu \& Tempat Penelitian}

Penelitian dilakukan di Pusat Penelitian Metalurgi - LIPI, Gedung 470 Kawasan PUSPIPTEK Serpong, Tangerang 15314. Penelitian dilakukan dari tanggal 8 Maret 2010 sampai dengan tanggal 9 Juli 2010.

\section{Bahan dan Alat}

Pasir kuarsa dari daerah Samboja, Samarinda, Kalimantan Timur. Natrium karbonat 
$\left(\mathrm{Na}_{2} \mathrm{CO}_{3}\right)$, zeolit hijau dari daerah Cidadap Karangnunggal, Tasikmalaya, Jawa Barat. Aquades, asam sulfat $\left(\mathrm{H}_{2} \mathrm{SO}_{4}\right) 1 \mathrm{~N}$, larutan standar logam $\mathrm{Fe}$, larutan standar logam $\mathrm{Mg}$, larutan standar logam Ca.

Peralatan yang digunakan terdiri dari alatalat-alat gelas, tanur, oven, krusibel tanah liat, corong, kertas saring Whatman No 40, gelas ukur, labu ukur, pipet ukur, pipet volum, timbangan analitik, grinder, penyaring ayakan ukuran lubang 50 mesh, termometer, hot plate, magnetik stirrer, desikator, kertas $\mathrm{pH}$ indikator universal Merck, AAS Analytic Jena NOV-AA 300, SEM-EDX JEOL JSM - 6390 A.

\section{Pemanggangan Pasir Kuarsa}

Pasir kuarsa yang digunakan adalah pasir yang berasal dari daerah Samboja, Kalimantan Timur. Pasir dicuci dengan menggunakan air bersih sampai hilang kotoran berupa humus maupun lumpur. Setelah bersih, ditandai dengan filtrat yang sudah jernih. Campuran dikeringkan dalam oven pada temperatur $110^{\circ} \mathrm{C}$ selama 1 jam. Pasir yang sudah kering ditimbang sebanyak 165 gram dan dicampur dengan 135 gram natrium karbonat $\left(\mathrm{Na}_{2} \mathrm{CO}_{3}\right)$, kemudian dicampur sampai merata dalam mixer. Setelah merata, campuran dimasukkan ke dalam krusibel tanah liat dan tanur diatur pada temperatur $1200^{\circ} \mathrm{C}$. Setelah tercapai temperatur $1200^{\circ} \mathrm{C}$, campuran ditahan dalam tanur selama 2 jam. Setelah itu, campuran dikeluarkan dalam kondisi cair dan dituangkan di tempat yang telah disediakan. Lelehan (natrium silikat) didinginkan pada temperatur ruang. Setelah dingin, natrium silikat digrinding sehingga menjadi bubuk.

\section{Preparasi Larutan Natrium Silikat 10\%}

Serbuk natrium silikat yang diperoleh dari roasting ditimbang sebanyak 20 gram. Sampel kemudian dilarutkan ke dalam $200 \mathrm{ml}$ air mendidih. Campuran diaduk selama 2 jam. Kemudian didinginkan pada temperatur ruang. Setelah itu, campuran disaring dengan kertas saring Whatman No 40. Filtrat yang dihasilkan dianalisa dengan AAS Analytic Jena novAA 300.

\section{Preparasi Zeolit}

Zeolit alam yang digunakan pada penelitian ini berasal dari daerah Cidadap, Karangnunggal. Zeolit yang digunakan berwarna hijau. Zeolit diperkecil ukurannya kurang lebih 2-3 $\mathrm{cm}$, kemudian digrinding sampai menjadi serbuk. Setelah itu disaring dengan penyaring ayakan berukuran lubang 50 mesh.

\section{Aktivasi Zeolit}

Menurut (Rustam, 2001) dan (Yuhelda, 2004), aktivasi zeolit dilakukan dengan pemanasan dan secara kimia. Pertama oven diatur pada temperatur $300^{\circ} \mathrm{C}$. Setelah tercapai temperatur yang diinginkan, 50 gram zeolit berukuran -50 mesh dimasukkan dan ditahan dalam oven selama 1 jam, kemudian zeolit didinginkan dalam desikator. Tahap selanjutnya zeolit hasil pemanasan dicampur ke dalam $500 \mathrm{ml} \mathrm{H}_{2} \mathrm{SO}_{4}$ dengan konsentrasi $1 \mathrm{~N}$, dan diaduk pada temperatur ruang selama 1 jam. Zeolit kemudian dicuci dengan aquades sampai $\mathrm{pH}$ filtrat sama dengan $\mathrm{pH}$ aquades. Tahap akhir zeolit disaring dengan kertas saring Whatman No 40 dan dikeringkan dalam oven pada temperatur $105^{\circ} \mathrm{C}$ selama 2 jam. Zeolit hasil pengeringan didinginkan dalam desikator dan siap untuk digunakan.

\section{Analisa SEM}

Sampel yang telah bersih dan kering ditempelkan pada sample holder dengan perekat dua sisi, dilanjutkan dengan pelapis tipis emas dalam mesin pelapis tipis (sputler). Kemudian dilakukan pengamatan struktur mikro dan komposisi kimianya dengan SEM pada $20 \mathrm{kV}$ dan perbesaran 1000 kali.

\section{Percobaan Batch}

Percobaan batch dilakukan untuk mengetahui adsorpsi $\mathrm{Fe}^{3+}, \mathrm{Mg}^{2+}$, dan $\mathrm{Ca}^{2+}$. Percobaan dilakukan dengan menambahkan zeolit (yang sudah diaktivasi) ke dalam larutan natrium silikat. Percobaan dilakukan dengan beberapa parameter untuk mengetahui kondisi optimum adsorpsi zeolit.

\section{Analisa $\mathrm{Fe}^{3+}$}

Variasi Waktu Kontak 
Sebanyak 1 gram zeolit yang sudah diaktivasi dicampur ke dalam 50 ml larutan natrium silikat $\left(\mathrm{Na}_{2} \mathrm{SiO}_{3}\right)$ 0,03\% dengan $\mathrm{pH}=$ 3. Kemudian diaduk pada temperatur $30^{\circ} \mathrm{C}$ dengan waktu yang berbeda $(15,30,60,90$, 120, 150 menit). Setelah itu campuran disaring dengan kertas saring Whatman No 40. Filtrat yang dihasilkan dianalisa menggunakan AAS Analytic Jena novAA 300 untuk mengetahui penyerapan zeolit.

\section{Variasi Massa Zeolit}

Zeolit yang sudah diaktivasi dengan massa yang berbeda (1, 2, 3, 4, 5, 7 gram) dicampur ke dalam $50 \mathrm{ml}$ larutan natrium silikat $\left(\mathrm{Na}_{2} \mathrm{SiO}_{3}\right) \quad 0,03 \%$ dengan $\mathrm{pH}=3$. Kemudian diaduk pada temperatur $30^{\circ} \mathrm{C}$ selama 60 menit. Setelah itu campuran disaring dengan kertas saring Whatman No 40. Filtrat yang dihasilkan dianalisa menggunakan AAS Analytic Jena novAA 300 untuk mengetahui penyerapan zeolit.

\section{Variasi $p H$}

Sebanyak 3 gram zeolit yang sudah diaktivasi dicampur ke dalam $50 \mathrm{ml}$ larutan natrium silikat $\left(\mathrm{Na}_{2} \mathrm{SiO}_{3}\right) \quad 0,03 \%$ dengan $\mathrm{pH}$ yang berbeda (2, 3, 4, 5, 6, 7, 8). Kemudian diaduk pada temperatur $30^{\circ} \mathrm{C}$ selama 60 menit. Setelah itu campuran disaring dengan kertas saring Whatman No 40. Filtrat yang dihasilkan dianalisa menggunakan AAS Analytic Jena novAA 300 untuk mengetahui penyerapan zeolit.

\section{Variasi Temperatur}

Sebanyak 3 gram zeolit yang sudah diaktivasi dicampur ke dalam $50 \mathrm{ml}$ larutan natrium silikat $\left(\mathrm{Na}_{2} \mathrm{SiO}_{3}\right)$ 0,03\% dengan $\mathrm{pH}=$ 3. Kemudian diaduk pada temperatur yang berbeda $\left(30,40,50,60,70,80^{\circ} \mathrm{C}\right)$ selama 60 menit. Setelah itu campuran disaring dengan kertas saring Whatman No 40. Filtrat yang dihasilkan dianalisa menggunakan AAS Analytic Jena novAA 300 untuk mengetahui penyerapan zeolit.

Isoterm Adsorpsi
Sebanyak 3 gram zeolit yang sudah diaktivasi dicampur ke dalam $50 \mathrm{ml}$ larutan natrium silikat $\left(\mathrm{Na}_{2} \mathrm{SiO}_{3}\right)$ dengan konsentrasi larutan yang berbeda $(0,1,0,07,0,05,0,04,0,03 \%)$ dengan $\mathrm{pH}=$ 3. Kemudian diaduk pada temperatur $30^{\circ} \mathrm{C}$ selama 60 menit. Setelah itu campuran disaring dengan kertas saring Whatman No 40. Filtrat yang dihasilkan dianalisa menggunakan AAS Analytic Jena novAA 300 untuk mengetahui penyerapan zeolit.

\section{Analisa $\mathrm{Mg}^{2+}$ dan $\mathrm{Ca}^{2+}$}

Variasi $\mathrm{pH}$

Sebanyak 2,5 gram zeolit yang sudah diaktivasi dicampur ke dalam $50 \mathrm{ml}$ larutan natrium silikat $\left(\mathrm{Na}_{2} \mathrm{SiO}_{3}\right) 0,1 \%$ dengan $\mathrm{pH}$ yang berbeda (2, 3, 4, 6, 8, 10). Kemudian diaduk pada temperatur $30^{\circ} \mathrm{C}$ selama 60 menit. Setelah itu campuran disaring dengan kertas saring Whatman No 40. Filtrat yang dihasilkan dianalisa menggunakan AAS Analytic Jena novAA 300 untuk mengetahui pada $\mathrm{pH}$ berapa penyerapan optimum zeolit.

\section{Variasi Massa Zeolit}

Zeolit yang sudah diaktivasi dengan massa yang berbeda (1, 3, 5, 7 gram) dicampur ke dalam $50 \mathrm{ml}$ larutan natrium silikat $\left(\mathrm{Na}_{2} \mathrm{SiO}_{3}\right) \quad 0,1 \%$ dengan $\mathrm{pH}=10$. Kemudian diaduk pada temperatur $30^{\circ} \mathrm{C}$ selama 60 menit. Setelah itu campuran disaring dengan kertas saring Whatman No 40. Filtrat yang dihasilkan dianalisa menggunakan AAS Analytic Jena novAA 300 untuk mengetahui penyerapan optimum zeolit.

\section{Variasi Waktu Kontak}

Sebanyak 2,5 gram zeolit yang sudah diaktivasi dicampur ke dalam $50 \mathrm{ml}$ larutan natrium silikat $\left(\mathrm{Na}_{2} \mathrm{SiO}_{3}\right)$ 0,1\% dengan $\mathrm{pH}=10$. Kemudian diaduk pada temperatur $30^{\circ} \mathrm{C}$ dengan waktu yang berbeda (5, 10, 20, 30, 40, 60 menit). Setelah itu campuran disaring dengan kertas saring Whatman No 40. Filtrat yang dihasilkan dianalisa menggunakan AAS Analytic Jena novAA 300 untuk mengetahui penyerapan optimum zeolit.

\section{HASIL DAN PEMBAHASAN}

Karakteristik Pasir Kuarsa 
Karakterisasi pasir kuarsa Semboja dilakukan menggunakan SEM dan AAS. Hasil analisa menggunakan SEM dengan perbesaran 500 kali menunjukkan morfologi permukaan pasir kuarsa. Dari gambar 1 terlihat bahwa hasil analisa ini identik dengan kuarsa komersil.

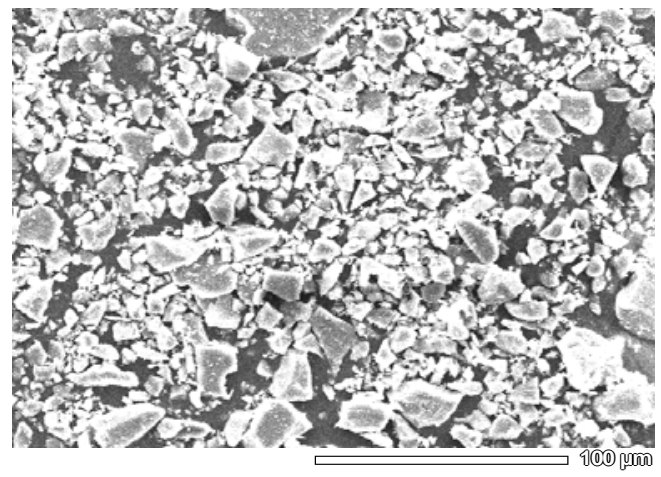

Gambar 1. Morfologi Pasir Kuarsa Samboja

Analisa menggunakan AAS juga dilakukan. Analisa ini dilakukan untuk mengetahui senyawa-senyawa pengotor apa saja yang terdapat di dalam pasir kuarsa. Hasil analisa AAS dapat dilihat pada tabel 1 . Berdasarkan analisa AAS diketahui bahwa senyawa pengotor terbesar adalah $\mathrm{Fe}_{2} \mathrm{O}_{3}$ sebesar 0,19\%.

Tabel 1. Hasil Analisa XRF Pasir Kuarsa Samboja

\begin{tabular}{|c|c|}
\hline Senyawa & Jumlah (\%) \\
\hline $\mathrm{SiO}_{2}$ & 99,2 \\
\hline $\mathrm{Fe}_{2} \mathrm{O}_{3}$ & 0,19 \\
\hline $\mathrm{Al}_{2} \mathrm{O}_{3}$ & 0,063 \\
\hline $\mathrm{TiO}_{2}$ & 0,048 \\
\hline $\mathrm{CaO}$ & 0,008 \\
\hline $\mathrm{MgO}$ & 0,008 \\
\hline $\mathrm{K}_{2} \mathrm{O}$ & 0,023 \\
\hline $\mathrm{Na}_{2} \mathrm{O}$ & 0,020 \\
\hline $\mathrm{LOI}$ & 0,39 \\
\hline
\end{tabular}

Sumber : Laboratorium Pengujian tekMIRA, Bandung

Preparasi Larutan Natrium Silikat
Pasir kuarsa yang direaksikan dengan natrium karbonat $\left(\mathrm{Na}_{2} \mathrm{CO}_{3}\right)$. akan melebur membentuk natrium silikat pada temperatur di atas $1200^{\circ} \mathrm{C}$. Selanjutnya leburan didinginkan dengan cepat agar kristal yang diperoleh dapat larut dalam air dengan mudah, reaksi yang terjadi adalah :

$\mathrm{Na}_{2} \mathrm{CO}_{3}(\mathrm{~s})+\mathrm{SiO}_{2}(\mathrm{~s}) \longrightarrow \mathrm{Na}_{2} \mathrm{SiO}_{3}(\mathrm{~s})+\mathrm{CO}_{2}(\mathrm{~g})$

Natrium karbonat $\left(\mathrm{Na}_{2} \mathrm{CO}_{3}\right)$ ditambahkan ke dalam krusibel yang sebelumnya diisi dengan pasir silika, kedua bahan akan berdisosiasi menghasilkan natrium silikat dengan melepaskan karbon dioksida $\left(\mathrm{CO}_{2}\right)$. Akhirnya, setelah proses peleburan dan degassing pada temperatur mencapai $1200^{\circ} \mathrm{C}$, cairan didinginkan hingga temperatur kamar.

Ion natrium terperangkap di dalam jaringan dan mengurangi jumlah jembatan/ikatan antar tetrahedral.. Kation $\mathrm{Na}^{+}$ini berpengaruh pada ukuran lubang/rongga dan diperkirakan terjadinya pembentukan klaster dan kation $\mathrm{Na}^{+}$tidak terdistribusi secara acak dalam jaringan. Namun meskipun berfungsi sebagai fluks, natrium oksida sendiri menyebabkan gelas dapat larut dalam air (Smallman, et al, 2000).

Titik leleh natrium silikat adalah sekitar $900^{\circ} \mathrm{C}$, dan keadaan berkaca dihasilkan jika pendinginan melewati suhu tersebut dilakukan dengan cepat. Produknya, yang disebut "kaca-air" bersifat larut air. Natrium silikat yang dihasilkan kemudian dilarutkan dengan air mendidih. Hanya silikat logam-logam alkali larut dalam air. Zat-zat ini terhidrolisis dalam larutan air dan karenanya menghasilkan larutan basa, reaksi yang terjadi adalah :

$\mathrm{SiO}_{3}{ }^{2-}+2 \mathrm{H}_{2} \mathrm{O} \longrightarrow \mathrm{H}_{2} \mathrm{SiO}_{3}+2 \mathrm{OH}^{-}$

Larutan natrium silikat ini kemudian direaksikan dengan zeolit untuk menghilangkan unsur pengotor yang terkandung di dalamnya. Proses adsorpsi dilakukan dengan metode batch.

\section{Aktivasi Zeolit}

Zeolit alam pada umumnya mempunyai ukuran pori-pori yang tidak sama. Aktivitas katalitik zeolit alam cenderung rendah dan banyak mengandung pengotor. Oleh karena itu, zeolit alam perlu diaktivasi dan dimodifikasi terlebih dahulu untuk meningkatkan manfaat dan kemampuannya (Pardoyo, et al, 2009). 
Aktivasi zeolit dimulai dengan pemanasan yang bertujuan untuk menguapkan air yang terdapat pada permukaan zeolit sampai ke seluruh rongga atau pori-pori zeolit. Hal ini juga berfungsi untuk menguraikan senyawa-senyawa organik yang terdapat di dalam rongga atau pori-pori zeolit (Parikesit, 2003). Penguapan molekul-molekul air yang terperangkap di dalam pori-pori zeolit menghasilkan jumlah pori dan luas permukaan spesifik zeolit bertambah sehingga zeolit menjadi lebih efektif mengadsorpsi ion-ion logam (Susatyo, et al, 2009).

Konsentrasi $\mathrm{H}_{2} \mathrm{SO}_{4}$ mempengaruhi adsorpsi ion logam. Asam sulfat digunakan untuk menghilangkan pengotor-pengotor yang terdapat di permukaan dan di dalam struktur zeolit sehingga zeolit menjadi lebih efektif mengadsorpsi ion-ion logam. Proses aktivasi dengan asam dapat meningkatkan kristalinitas, keasaman dan luas permukaan. Peningkatan keasaman zeolit mampu memperbesar kemampuan penyerapan zeolit. Hal itu terjadi karena banyaknya pori-pori zeolit yang terbuka dan permukaan padatannya menjadi bersih dan luas (Heraldy, et al, 2003).

Zeolit alam Karangnunggal yang sudah diaktivasi dan akan digunakan untuk proses selanjutnya dianalisa menggunakan SEM. Hasil analisa SEM dapat dilihat pada gambar 2. Hasil analisa menggunakan SEM dengan perbesaran 1000 kali menunjukkan morfologi permukaan zeolit.

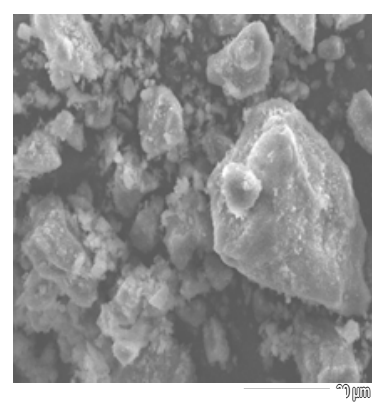

Sebelum aktivasi

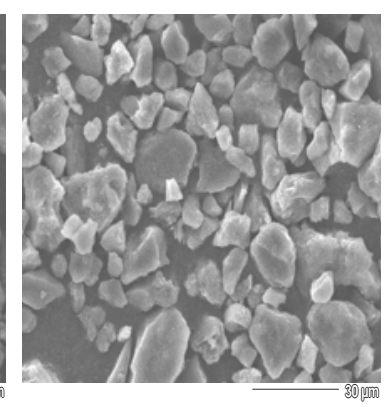

Ssetelah aktivasi
Gambar 2. Zeolit sebelum dan setelah diaktivasi

Dari gambar 2 dapat dilihat bahwa zeolit yang sudah diaktivasi permukaannya lebih bersih dari pengotor. Selain itu, zeolit yang sudah diaktivasi mempunyai ukuran partikel yang lebih kecil dan hampir sama. Semakin kecil ukuran partikel maka akan semakin efektif untuk menyerap unsur pengotor dalam larutan natrium silikat.

SEM yang digunakan pada analisa ini dilengkapi dengan EDX (Energy Dispersive $X$-ray spectrometer), sehingga dapat digunakan untuk menentukan komposisi unsur dari sampel. Ketika sebuah sampel difoto oleh SEM, sinar elektron juga diemisikan oleh sinar-X yang kemudian diteruskan menuju EDX. Emisi sinar-X setiap unsur khas dalam energi dan panjang gelombangnya, karena itu unit EDX mampu menentukan setiap unsur yang merespon emisi tersebut. Data ini dapat ditambahkan pada gambar SEM untuk menghasilkan sebuah peta unsur yang sebenarnya dari permukaan sampel (Heraldy, et.al, 2003).

Tabel 2. Hasil Analisa EDX Zeolit Alam Karangnunggal

\begin{tabular}{|c|c|c|}
\hline Unsur & $\begin{array}{c}\text { Zeolit Tanpa } \\
\text { Aktivasi (\% } \\
\text { massa) }\end{array}$ & $\begin{array}{c}\text { Zeolit yang } \\
\text { Sudah } \\
\text { Diaktivasi (\%) } \\
\text { massa) }\end{array}$ \\
\hline $\mathrm{C}$ & 33,54 & 31,42 \\
\hline $\mathrm{O}$ & 42,91 & 41,70 \\
\hline $\mathrm{Na}$ & 0,50 & - \\
\hline $\mathrm{Al}$ & 2,92 & 3,35 \\
\hline $\mathrm{Si}$ & 17,21 & 21,84 \\
\hline $\mathrm{K}$ & 0,80 & 0,71 \\
\hline $\mathrm{Ca}$ & 0,98 & 0,99 \\
\hline $\mathrm{Cu}$ & 1,14 & - \\
\hline
\end{tabular}

Tabel 2 menunjukkan hasil analisa EDX zeolit alam Karangnunggal. Dari tabel 7 dapat dilihat bahwa zeolit tanpa aktivasi masih mengandung logam pengotor. Logam pengotor yang paling banyak adalah $\mathrm{Cu}$. Sedangkan zeolit yang sudah diaktivasi sudah tidak mengandung logam $\mathrm{Cu}$ dan Na. Tetapi pada zeolit yang sudah diaktivasi mengalami penurunan kadar $\mathrm{Al}$, hal ini dapat dilihat dari rasio $\mathrm{Si} / \mathrm{Al}$ zeolit. Rasio $\mathrm{Si} / \mathrm{Al}$ pada zeolit tanpa aktivasi adalah 5,89 sedangkan zeolit yang sudah diaktivasi adalah 6,52. Semakin kecil kadar Al dalam zeolit maka semakin besar rasio Si/Al. Penurunan kadar $\mathrm{Al}$ pada zeolit yang sudah diaktivasi dikarenakan penambahan $\mathrm{H}_{2} \mathrm{SO}_{4}$ yang menyebabkan zeolit mengalami dealuminasi (lepasnya $\mathrm{Al}$ dari struktur zeolit). Zeolit yang diaktivasi dengan $\mathrm{H}_{2} \mathrm{SO}_{4}$ akan membentuk $\mathrm{H}$ zeolit. 


\section{Hubungan Waktu Kontak dengan Penyerapan $\mathrm{Fe}^{3+}$}

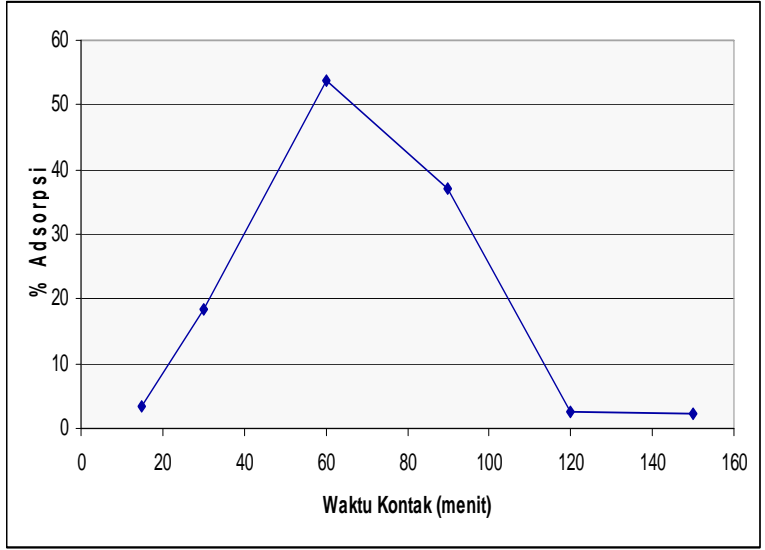

Gambar 3. Persentase ion logam $\mathrm{Fe}^{3+}$ yang diserap dari larutan natrium silikat dengan waktu kontak yang berbeda (massa zeolit $1 \mathrm{gr}, \mathrm{pH}=3$, temperatur $30^{\circ} \mathrm{C}$, volume $50 \mathrm{ml}$, konsentrasi 0,03\%).

Waktu kontak mempengaruhi adsorpsi ion logam $\mathrm{Fe}^{3+}$ dalam larutan natrium silikat. Dari gambar 3 dapat dilihat bahwa adsorpsi optimum dihasilkan pada larutan natrium silikat yang direaksikan dengan zeolit selama 60 menit, yaitu sebesar 53,64 \%. Berdasarkan perhitungan dengan menggunakan persamaan Isoterm Langmuir dan Freundlich dapat diketahui bahwa proses adsorpsi yang terjadi adalah adsorpsi fisika. Sehingga ikatan yang terjadi merupakan ikatan lemah.

\section{Hubungan Massa Zeolit dengan Penyerapan $\mathrm{Fe}^{3+}$}

Banyaknya massa zeolit yang direaksikan mempengaruhi adsorpsi ion logam $\mathrm{Fe}^{3+}$ dalam larutan natrium silikat. Bertambahnya massa zeolit sebanding dengan bertambahnya sisi aktif dan pori-pori zeolit. Sehingga menyebabkan proses adsorpsi ion logam $\mathrm{Fe}^{3+}$ lebih efektif.

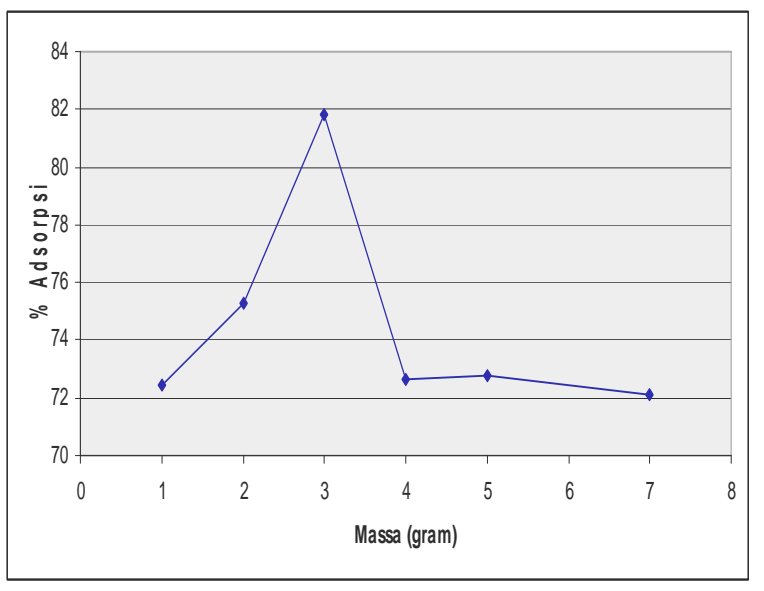

Gambar 4. Persentase ion logam $\mathrm{Fe}^{3+}$ yang diserap dari larutan natrium silikat dengan massa zeolit yang berbeda $\left(\mathrm{pH}=3\right.$, temperatur $30^{\circ} \mathrm{C}$, waktu kontak 60 menit, volume $50 \mathrm{ml}$, konsentrasi 0,03\%).

Gambar 4 menunjukkan bahwa adsorpsi optimum dihasilkan pada larutan yang direaksikan dengan 3 gram zeolit, yaitu sebesar 81,81 \%. Larutan yang direaksikan dengan massa zeolit kurang dari 3 gram belum optimal. Hal ini dikarenakan kurangnya sisi aktif dan ronggarongga zeolit untuk menyerap ion logam $\mathrm{Fe}^{3+}$. Larutan yang direaksikan dengan massa zeolit lebih dari 3 gram juga tidak optimal. Hal ini kemungkinan dikarenakan dengan semakin banyaknya jumlah zeolit yang digunakan, larutan natrium silikat menjadi semakin asam. Kondisi $\mathrm{pH}$ larutan yang semakin asam memungkinkan terjadinya reaksi pelepasan ion $\mathrm{Fe}^{3+}$ kembali.

\section{Hubungan pH dengan Penyerapan $\mathrm{Fe}^{3+}$}

Kemampuan penyerapan suatu sorben dapat dipengaruhi oleh $\mathrm{pH}$ larutan. Hal ini berhubungan dengan protonasi atau deprotonasi permukaan sisi aktif dari sorben (Nurhasni, 2002). Keasaman dan kebasaan larutan natrium silikat mempengaruhi adsorpsi ion logam $\mathrm{Fe}^{3+}$. Dari gambar 10 dapat dilihat bahwa adsorpsi optimum dihasilkan pada larutan natrium silikat dengan $\mathrm{pH}$ 3 , yaitu sebesar 76,05 \%. Adsorpsi ion logam $\mathrm{Fe}$ pada larutan natrium silikat dengan $\mathrm{pH}$ kurang dari 3 tidak optimal. Hal ini dikarenakan konsentrasi $\mathrm{H}^{+}$ yang terlalu besar, sehingga terjadi kompetisi antara $\mathrm{H}^{+}$dengan alkali dan alkali tanah yang terdapat di dalam kerangka zeolit. Kompetisi ini 
mengakibatkan terganggunya proses pertukaran ion dan penyerapan terhadap ion logam $\mathrm{Fe}^{3+}$.

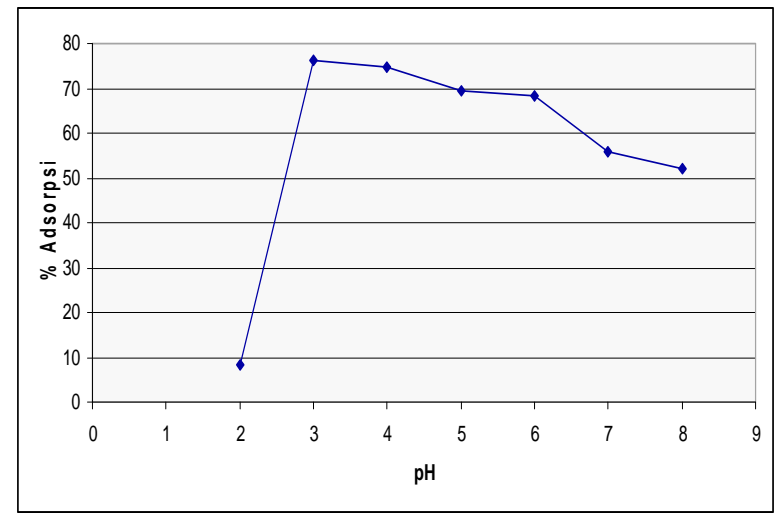

Gambar 5. Persentase ion logam $\mathrm{Fe}^{3+}$ yang diserap dari larutan natrium silikat dengan $\mathrm{pH}$ larutan yang berbeda (massa zeolit $3 \mathrm{gr}$, temperatur $30^{\circ} \mathrm{C}$, waktu kontak 60 menit, volume $50 \mathrm{ml}$, konsentrasi $0,03 \%)$.

\section{Hubungan Temperatur dengan Penyerapan $\mathrm{Fe}^{3+}$}

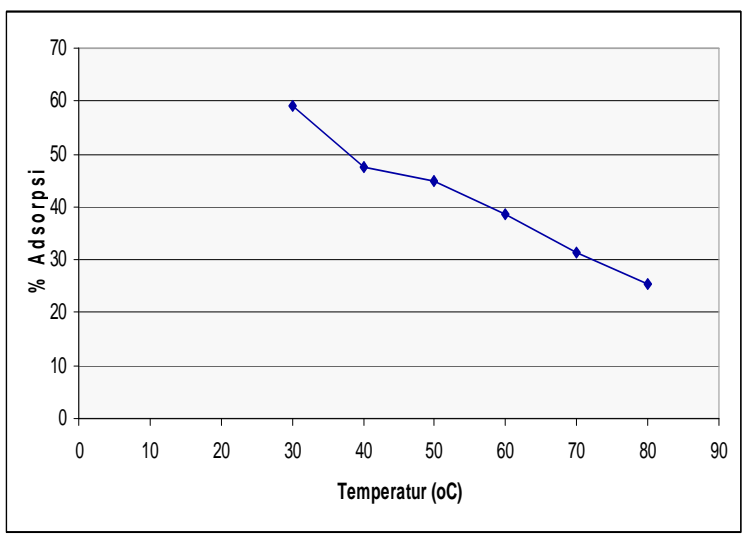

Gambar 6. Persentase ion logam $\mathrm{Fe}^{3+}$ yang diserap dari larutan natrium silikat dengan temperatur larutan yang berbeda (massa zeolit 3 gr, $\mathrm{pH}=3$, waktu kontak 60 menit, volume $50 \mathrm{ml}$, konsentrasi $0,03 \%)$.

Temperatur reaksi mempengaruhi adsorpsi ion logam $\mathrm{Fe}^{3+}$ dalam larutan natrium silikat. Dari gambar 6 dapat dilihat bahwa adsorpsi optimum dihasilkan pada larutan yang direaksikan pada temperatur $30^{\circ} \mathrm{C}$, yaitu sebesar 59,13\%. Semakin tinggi temperatur reaksi, semakin rendah penyerapan ion logam $\mathrm{Fe}^{3+}$. Hal ini dikarenakan dengan semakin tinggi temperatur maka akan menyebabkan pecahnya struktur zeolit. Sehingga menyebabkan kalsit $\left(\mathrm{CaCO}_{3}\right)$ yang tersisa dalam struktur zeolit keluar dan mengganggu penyerapan ion logam $\mathrm{Fe}^{3+}$. Kemungkinan lainnya karena semakin tinggi temperatur pada proses adsorpsi, maka pergerakan ion logam $\mathrm{Fe}^{3+}$ semakin cepat. Sehingga jumlah ion logam $\mathrm{Fe}^{3+}$ yang terserap oleh zeolit semakin berkurang (Kundari dan Slamet, 2008).

\section{Isoterm Adsorpsi $\mathrm{Fe}^{3+}$}
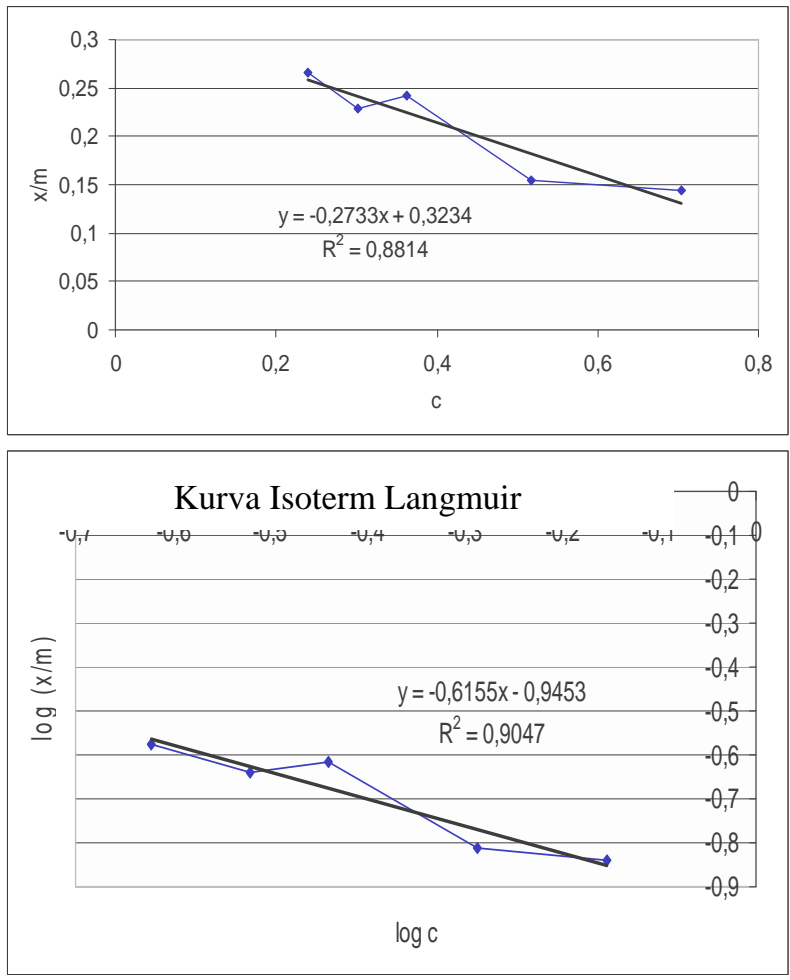

Kurva Isoterm Freundlich Langmuir

Gambar 7. Grafik isoterm adsorpsi $\mathrm{Fe}^{3+}$ oleh zeolit (massa zeolit $3 \mathrm{gr}, \mathrm{pH}=3$, temperatur $30^{\circ} \mathrm{C}$, waktu kontak 60 menit, volume $50 \mathrm{ml}$, konsentrasi 0,03\%).

Percobaan isoterm adsorpsi dilakukan untuk mengetahui jenis adsorpsi yang terjadi. Langmuir menggambarkan ikatan yang terjadi pada proses adsorpsi adalah ikatan kimia, sedangkan Freundlich menggambarkan ikatan yang terjadi pada proses adsorpsi adalah ikatan fisika. Gambar 12 memperlihatkan grafik hasil perhitungan secara Langmuir dan Freundlich. Dari gambar 12 dapat dilihat bahwa nilai koefisien determinasi $\left(\mathrm{R}^{2}\right)$ dari 
persamaan isoterm Freundlich adalah 0,9047, sedangkan isoterm Langmuir sebesar 0,8814. Hal ini menunjukkan bahwa ikatan yang terjadi pada proses adsorpsi $\mathrm{Fe}^{3+}$ oleh zeolit alam Karangnunggal didominasi oleh ikatan fisika, karena koefisien determinasi isoterm Freundlich lebih besar. Namun, tidak menutup kemungkinan terjadinya ikatan kimia. Ikatan yang terjadi disebabkan adanya gaya Van der Waals yang ikatannya lemah, sehingga sorbat yang sudah terikat mudah terlepas kembali.

\section{Hubungan $\mathrm{pH}$ dengan Penyerapan $\mathrm{Mg}^{2+}$ dan $\mathrm{Ca}^{2+}$}

Kemampuan penyerapan suatu sorben dapat dipengaruhi oleh $\mathrm{pH}$ larutan. Hal ini berhubungan dengan protonasi atau deprotonasi permukaan sisi aktif dari sorben (Nurhasni, 2002). Keasaman dan kebasaan larutan natrium silikat mempengaruhi adsorpsi ion logam $\mathrm{Mg}^{2+}$ dan ion logam $\mathrm{Ca}^{2+}$. Dari tabel 8 dapat dilihat bahwa zeolit hijau tidak dapat menyerap ion logam $\mathrm{Mg}^{2+}$ dan ion logam $\mathrm{Ca}^{2+}$ dalam berbagai $\mathrm{pH}$ baik asam maupun basa. Zeolit hijau tidak dapat menyerap ion logam $\mathrm{Mg}^{2+}$ dan ion logam $\mathrm{Ca}^{2+}$ dikarenakan zeolit hijau mengandung senyawa $\mathrm{MgO}$ dan $\mathrm{CaO}$

Tabel 3. Hasil Analisa Penyerapan $\mathrm{Mg}^{2+}$ dan $\mathrm{Ca}^{2+}$ terhadap Pengaruh $\mathrm{pH} \quad$ Larutan Natrium Silikat (massa zeolit 2,5 gr, temperatur $30^{\circ} \mathrm{C}$, waktu kontak 60 menit, volume $50 \mathrm{ml}$, konsentrasi 0,1\%).

\begin{tabular}{|c|c|c|c|c|}
\hline \multirow{2}{*}{$\mathbf{p H}$} & \multicolumn{2}{|c|}{ Ion Logam $\mathbf{M g}^{2+}$} & \multicolumn{2}{c|}{ Ion Logam $\mathbf{C a}^{2+}$} \\
\cline { 2 - 5 } & $\begin{array}{c}\text { Co } \\
\text { (ppm) }\end{array}$ & $\begin{array}{c}\text { Ce } \\
\text { (ppm) }\end{array}$ & $\begin{array}{c}\text { Co } \\
\text { (ppm) }\end{array}$ & $\begin{array}{c}\text { Ce } \\
(\mathbf{p p m})\end{array}$ \\
\hline 2 & 0,07468 & 0,1752 & 0,6663 & 10,96 \\
3 & 0,05490 & 0,1783 & 0,3450 & 9,7820 \\
4 & 0,06129 & 0,1808 & 0,3821 & 10,04 \\
6 & 0,04703 & 0,1855 & 0,2863 & 9,0590 \\
8 & 0,06274 & 0,1838 & 0,5174 & 8,9290 \\
10 & 0,05203 & 0,08349 & 0,3334 & 0,4599 \\
\hline
\end{tabular}

Keterangan : $\mathrm{Co}=$ Konsentrasi Awal $\mathrm{Ce}=$ Konsentrasi Akhir

Ion-ion logam tersebut tidak dapat diserap pada suasana asam karena logam magnesium dan kalsium yang terdapat di dalam zeolit ikut larut dalam larutan natrium silikat. Hal tersebut mengakibatkan terjadinya peningkatan konsentrasi ion logam $\mathrm{Mg}^{2+}$ dan ion logam $\mathrm{Ca}^{2+}$ setelah proses adsorpsi. Peningkatan konsentrasi ion logam $\mathrm{Mg}^{2+}$ dan ion logam $\mathrm{Ca}^{2+}$ yang tidak terlalu besar didapat pada larutan natrium silikat dengan $\mathrm{pH}$ basa $(\mathrm{pH} 10)$. Hal ini dikarenakan pada $\mathrm{pH} 10$ ion logam $\mathrm{Mg}^{2+}$ mulai mengendap. Sedangkan pada $\mathrm{pH}$ lebih dari 10 ionion logam tersebut sudah mengalami pengendapan (Svehla, 1985).

\section{Hubungan Massa Zeolit dengan Penyerapan $\mathrm{Mg}^{2+}$ dan $\mathrm{Ca}^{2+}$}

Tabel 4. Hasil Analisa Penyerapan $\mathrm{Mg}^{2+}$ dan $\mathrm{Ca}^{2+}$ terhadap Pengaruh Massa Zeolit $(\mathrm{pH}=10$, temperatur $30^{\circ} \mathrm{C}$, waktu kontak 60 menit, volume $50 \mathrm{ml}$, konsentrasi 0,1\%).

\begin{tabular}{|c|c|c|c|c|c|}
\hline \multirow{2}{*}{$\begin{array}{c}\text { Massa } \\
\text { (gram) }\end{array}$} & \multicolumn{2}{|c|}{ Ion Logam $\mathbf{M g}^{2+}$} & \multicolumn{2}{|c|}{ Ion Logam Ca $\mathbf{C a}^{2+}$} & pH Stlh \\
\cline { 2 - 5 } & $\begin{array}{c}\mathbf{C o} \\
\text { (ppm) }\end{array}$ & $\begin{array}{c}\mathbf{C e} \\
\text { (ppm) }\end{array}$ & $\begin{array}{c}\text { Co } \\
\text { (ppm) }\end{array}$ & $\begin{array}{c}\text { Ce } \\
\text { (ppm) }\end{array}$ & \\
\hline 1 & 0,03236 & 0,06055 & 0,1960 & 0,5716 & 9 \\
3 & 0,03236 & 0,06129 & 0,1960 & 0,5906 & 5 \\
5 & 0,03236 & 0,06918 & 0,1960 & 0,8139 & 5 \\
7 & 0,03236 & 0,07029 & 0,1960 & 0,8441 & 5 \\
\hline
\end{tabular}

Keterangan : Co $=$ Konsentrasi Awal $\mathrm{Ce}=$ Konsentrasi Akhir

Bertambahnya massa zeolit sebanding dengan bertambahnya sisi aktif dan pori-pori zeolit, sehingga semakin banyak massa zeolit yang direaksikan akan meningkatkan adsorpsi ion logam $\mathrm{Mg}^{2+}$ dan ion logam $\mathrm{Ca}^{2+}$ dalam larutan natrium silikat. Dari tabel 9 dapat dilihat bahwa zeolit hijau tidak dapat menyerap ion logam $\mathrm{Mg}^{2+}$ dan ion logam $\mathrm{Ca}^{2+}$ dalam berbagai massa zeolit yang digunakan. Hal ini dikarenakan terjadinya penurunan $\mathrm{pH}$ setelah proses adsorpsi. Penurunan $\mathrm{pH}$ terjadi karena zeolit yang digunakan sudah diaktivasi dengan asam. Semakin banyak massa zeolit yang digunakan filtrat yang dihasilkan semakin keruh. Hal ini mungkin dikarenakan semakin banyaknya logam magnesium dan kalsium yang terlarut dalam larutan natrium silikat. Hasil percobaan menunjukkan bahwa setelah proses adsorpsi menggunakan 1 gram zeolit $\mathrm{pH}$ berubah dari 10 menjadi 9, sedangkan proses adsorpsi menggunakan 7 gram zeolit $\mathrm{pH}$ berubah dari 10 menjadi 5. 


\section{Hubungan Waktu Kontak dengan Penyerapan $\mathrm{Mg}^{2+}$ dan $\mathrm{Ca}^{2+}$}

Tabel 10. Hasil Analisa Penyerapan $\mathrm{Mg}^{2+}$ dan $\mathrm{Ca}^{2+}$ terhadap Pengaruh Waktu Kontak (massa zeolit $2,5 \mathrm{gr}, \mathrm{pH}=10$, temperatur $30^{\circ} \mathrm{C}$, volume 50 $\mathrm{ml}$, konsentrasi $0,1 \%$ ).

\begin{tabular}{|c|c|c|c|c|c|}
\hline $\begin{array}{c}\text { Waktu } \\
\text { Kontak } \\
\text { (menit) }\end{array}$ & \multicolumn{2}{|c|}{$\begin{array}{c}\text { Ion Logam } \\
\mathbf{M g}^{2+}\end{array}$} & \multicolumn{2}{c|}{$\begin{array}{c}\text { Ion Logam } \\
\mathbf{C a}^{2+}\end{array}$} & $\begin{array}{c}\text { pH } \\
\text { Setelah } \\
\text { Adsorps } \\
\text { i }\end{array}$ \\
\cline { 2 - 5 } & $\begin{array}{c}\text { Co } \\
\text { (ppm) }\end{array}$ & $\begin{array}{c}\text { Ce } \\
\text { (ppm) }\end{array}$ & $\begin{array}{c}\text { Co } \\
\text { (ppm) }\end{array}$ & $\begin{array}{c}\text { Ce } \\
\text { (ppm) }\end{array}$ & \\
\hline 5 & 0,0311 & 0,0580 & 0,1787 & 0,6842 & 9 \\
10 & 7 & 8 & 0,1787 & 0,7207 & 9 \\
20 & 0,0311 & 0,0585 & 0,1787 & 0,7553 & 8 \\
30 & 7 & 4 & 0,1787 & 0,7022 & 6 \\
40 & 0,0311 & 0,0593 & 0,1787 & 0,6978 & 6 \\
60 & 7 & 4 & 0,1787 & 0,7139 & 5 \\
& 0,0311 & 0,0551 & & & \\
& 7 & 6 & & & \\
& 0,0311 & 0,0625 & & & \\
& 7 & 1 & & & \\
& 0,0311 & 0,0734 & & & \\
\hline & 7 & 9 & & & \\
\hline
\end{tabular}

Keterangan : Co $=$ Konsentrasi Awal

$\mathrm{Ce}=$ Konsentrasi Akhir

Waktu kontak mempengaruhi adsorpsi ion logam $\mathrm{Mg}^{2+}$ dan ion logam $\mathrm{Ca}^{2+}$ dalam larutan natrium silikat. Dari tabel 10 dapat dilihat bahwa zeolit hijau tidak dapat menyerap ion logam $\mathrm{Mg}^{2+}$ dan ion logam $\mathrm{Ca}^{2+}$ dalam berbagai waktu kontak yang dilakukan. Hal ini dikarenakan terjadinya penurunan $\mathrm{pH}$ setelah proses adsorpsi. Semakin lama proses adsorpsi yang dilakukan maka $\mathrm{pH}$ semakin turun. Penurunan $\mathrm{pH}$ terjadi karena zeolit yang digunakan sudah diaktivasi dengan asam. Sehingga selama proses adsorpsi terjadi pelepasan ion $\mathrm{H}^{+}$di dalam larutan natrium silikat. Hasil percobaan menunjukkan bahwa setelah proses adsorpsi selama 5 menit $\mathrm{pH}$ berubah dari 10 menjadi 9 , sedangkan setelah proses adsorpsi selama 60 menit $\mathrm{pH}$ berubah dari 10 menjadi 5.

\section{KESIMPULAN DAN SARAN}

\section{Kesimpulan}

1. Kondisi optimum adsorpsi $\mathrm{Fe}^{3+}$ dalam larutan natrium silikat dicapai dengan parameter waktu kontak selama 60 menit (penyerapan 53,64\%), massa zeolit yang digunakan sebanyak 3 gram (penyerapan
81,81\%), pH = 3 (penyerapan 76,05\%), dan pada temperatur $30^{\circ} \mathrm{C}$ (penyerapan 59,13\%).

2. Proses adsorpsi $\mathrm{Fe}^{3+}$ dalam larutan natrium silikat didominasi oleh adsorpsi fisika.

3. Zeolit alam Karangnunggal yang diaktivasi dengan $\mathrm{H}_{2} \mathrm{SO}_{4}$ tidak bisa digunakan untuk menyerap $\mathrm{Mg}^{2+}$ dan $\mathrm{Ca}^{2+}$ dalam larutan natrium silikat. Hal ini dikarenakan zeolit yang digunakan mengandung $\mathrm{MgO}$ dan $\mathrm{CaO}$.

4. Zeolit yang digunakan perlu dimodifikasi menjadi zeolit unikation (Na-zeolit) dengan cara perendaman dengan $\mathrm{NaCl}$.

\section{Saran}

Perlu dilakukan penelitian lebih lanjut mengenai kemampuan zeolit alam Karangnunggal untuk menyerap ion-ion logam lain dalam larutan natrium silikat, supaya dapat diperoleh informasi tentang kemampuan zeolit sebagai sorben. Selain itu juga perlu dilakukan penelitian lebih lanjut mengenai parameter lain yang berpengaruh terhadap penyerapan zeolit.

\section{UCAPAN TERIMA KASIH}

Pada kesempatan ini penulis mengucapkan terimakasih kepada Kepala Pusat Penelitian Metalurgi LIPI Gedung 470 Kawasan PUSPIPTEK Serpong atas kesempatannya untuk melakukan penelitian ini.

\section{DAFTAR PUSTAKA}

1. Stanitski, Conrad L. 2003. Chemistry in Context : Applying Chemistry to Society $-4^{\text {th }}$ ed. New York : Mc Graw - Hill

2. Sulistiyono, Eko. 2005. Kajian Proses Ekstraksi Unsur Besi dari Pasir Kuarsa. Prosiding Seminar Material Metalurgi, Hal 416-420. Serpong : Lembaga Ilmu Pengetahuan Indonesia

3. Sulistiyono, Eko, Edi Harianto. 2000. Pencucian Kuarsa dari Tuban Menggunakan Larutan $\mathrm{HCl}$. Jurnal Metalurgi Vol 15, No 1, 25-30

4. Sulistiyono, Eko, Murni Handayani. 2009. Uji karakteristik Zeolit Hijau dan Putih dari Karangnunggal Tasikmalaya. Prosiding Seminar Nasional Kimia dan Pendidikan Kimia, Hal 360366. Semarang : Lembaga Ilmu Pengetahuan Indonesia 
5. Suhala, Supriatna, M. Arifin. 1997. Bahan Galian Industri. Bandung : Pusat Penelitian dan Pengembangan Teknologi Mineral

6. Dyer, A. 1988. An Introduction to Zeolite Molecular Sieves. Chichester : John Willey and Sons

7. Las, Thamzil. 2006. Mengenal Mineral Zeolit. Saintika, Jurnal Sains dan Teknologi UIN Syarif Hidayatullah Jakarta, Vol III, No.1, Hal. 64-75

8. Handayani, Murni, Eko Sulistyono. 2009. Kinetika Adsorpsi Zeolit Hijau Daerah Cidadap Tasikmalaya, Jawa Barat terhadap Larutan Ion Chromium (VI). Prosiding Seminar Kimia dan Pendidikan Kimia, Hal 278-288. Surakarta : Lembaga Ilmu Pengetahuan Indonesia

9. Yuhelda. 2004. Adsorpsi Nikel dan Krom dalam Limbah Cair Elektropleting PT. Dirgantara Indonesia dengan Zeolit Karangnunggal. Buletin Bahan Galian Industri, Volume 8, No 22

10. Rustam, Didi. 2001. Pengaruh Aktivasi Asam dan Basa Terhadap Zeolit Alam Tasikmalaya sebagai Penyerap Ion $\mathrm{Ca}^{2+}$ dan $\mathrm{Mg}^{2+}$ dalam Air Sadah. Skripsi. Depok : Universitas Indonesia

11. Smallman, R.E, RJ Bishop. 2000. Metalurgi Fisik Modern dan Rekayasa Material. Jakarta : Erlangga

12. Pardoyo, Listiana, Adi Darmawan. 2009. Pengaruh Perlakuan HCl pada Rasio Si/Al dan Kemampuan Adsorpsi Zeolit Alam terhadap Ion Logam $\mathrm{Ca}^{2+}$. Prosiding Seminar Nasional Kimia dan Pendidikan Kimia, Hal 325-329. Semarang : Lembaga Ilmu Penelitian Indonesia

13. Susatyo, Eko Budi, Sukirno, Ajeng Gumilaras. 2009. Sintesis Zeolit dari Abu Sekam Padi dengan Variasi Suhu Reaksi serta Aplikasinya sebagai Adsorben Ion $\mathrm{Cu}^{2+}$. Prosiding Seminar Nasional Kimia dan Pendidikan Kimia, Hal 343-351. Semarang : Lembaga ilmu Pengetahuan Indonesia

14. Heraldy, E, Hisyam SW, dan Sulistiyono. 2003. Characterization and Activation of Natural Zeolite from Ponorogo. Indonesian J. Chem 3 (2)

15. Nurhasni, 2002. Penyerapan Ion Logam Kadmium dan Tembaga oleh Genjer (Limnocharis Flava). Tesis. Padang : Universitas Andalas
16. Kundari, N.A, Slamet Wiyuniati. 2008. Tinjauan Kesetimbangan Adsorpsi Tembaga dalam Limbah Pencuci PCB dengan Zeolit. Seminar Nasional IV SDM Teknologi Nuklir, Hal 320-327

17. Svehla, G. 1985. Buku Teks Analisis Anorganik Kualitatif Makro dan Semimikro Bagian II. Jakarta : PT Kalman Media Pustaka 